\title{
В.П. Решетило
}

Харківський національний університет міського господарства імені О.М. Бекетова, Украӥна

\section{ІСТОРИЧНІ ВИТОКИ ФОРМУВАННЯ КИТАЙСЬКОЇ МОДЕЛІ ЕКОНОМІКИ}

В історичному контексті проаналізовано витоки становлення китайськой моделі економіки як розвитку основних рис азійського способу виробництва та конфуціанської моделі держави, з виокремленням національної специфіки. Розглянуто ключові особливості китайської моделі економіки, основні етапи ї̈ становлення та розвитку, проаналізовані основні риси промислової, інвестиційної, зовнішньоекономічної та соиіальної політики Китаю в умовах глобалізації.

Ключові слова: азійський спосіб виробництва, конфуціанська модель держави, китайська модель економіки, реформи, економічний розвиток, реальна економіка.

\section{Постановка проблеми}

Економічні успіхи Китаю останніх десятиріч, які дозволили країні стати другою економікою світу та лідером глобалізації, роблять цю країну і їі історію актуальним предметом дослідження. Країна, яка ще 25 років тому була бідною сільськогосподарською країною світу, сьогодні є одним із найвпливовіших суб'єктів світової економіки. За даними Світового банку, КНР займає перше місце в світі по розміру ВВП за паритетом купівельної спроможності $(19,8$

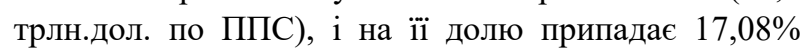
світового ВВП. КНР займає перше місце в світі по обсягу сукупного експорту та валових інвестицій [1].

В 2020 році на фоні світової пандеміі, не дивлячись на світову економічну кризу, Китай є єдиною країною світу, ВВП якої зростав, хоча і меншими темпами, ніж в 1990-ті роки та на початку 2000-х. Завершуючи виконання тринадцятого п'ятирічного плану (2016-2020 рр.), за підсумками 2020 р. зростання ВВП Китаю склало 2,3\% в річному обчисленні, а обсяг ВВП склав 101,6 трлн. юанів $(15,42$ трлн. дол. США) [2]. На фоні падіння світового ВВП більш ніж на 4\%, економіка Китаю продемонструвала економічне зростання, при якому питома вага доданої вартості в ВВП склала 54,5\% і зросла на $0,2 \%$ в річному обчисленні [2]. Можна говорити про те, що в дуже важкому 2020 році Китай добився значного успіху і заклав нові цеглини в формуванні фундаменту особливої моделі економіки.

Аналіз тисячолітньої економічної історії Китаю показує, що країна мала певні економічні успіхи ще в XVIII ст., коли Китай за обсягами ВВП також був першою країною світу. Але ефективність так званої китайської моделі економіки була продемонстрована в кінці XX - на початку XXI ст. Країна безумовно створила власну економічну модель, в якій використовуються сильні сторони централізованого державного управління в поєднанні з ринковими механізмами конкуренції.

\section{Аналіз останніх досліджень і публікацій}

Дослідження економічного розвитку Китаю можна знайти в роботах зарубіжних вчених Б. Нотона, Л. Вонга, Г. Женга, С. Кука, Н. Кабіра, Г. Суваннарата, І. Г. Калабекова, А.К. Нестерова, В.Н. Усова, а також в вітчизняних публікаціях В.Ю. Голода, А.З. Гончарука, О.В. Дроботюк, А.В. Длугопольськго, А.В. Срмолаєва, В.О. Кіктенко, О.В. Хоменко та інших. Великий аналітичний матеріал з історії та сьогодення Китаю можна знайти на сторінках журналу «Україна - Китай», який видається в Україні з 1999 року. Особливо інформативним є №3 (17) журналу «Україна Китай» за 2019 рік, присвячений 70-річчю утворення КНР [див. 3].

\section{Формулювання мети статті}

Мета статті - дослідження історичних витоків формування китайської моделі економіки та особливостей і факторів розвитку економіки Китаю в сучасних умовах, виявлення основних рис, місця i ролі китайської моделі економіки в світовому економічному розвитку.

\section{Виклад основного матеріалу}

Історичні витоки формування китайської моделі економіки вбачаються в особливому, азійському способі виробництва, класичним прикладом якого був перш за все Китай. Головна особливість азійського способу виробництва - державна власність на землю - залишається майже непорушною на протязі всієї історії Китаю. Ще одна важлива риса азійського способу виробництва визначальна роль держави в економічному розвитку - також характерна для економіки Китаю на 
всіх етапах його історичного розвитку.

Ще до н.е. державна земля ділилась поміж селянами по общинному принципу землекористування, який отримав назву «колодязних полів». Таку назву цей принцип отримав тому, що схема розміщення полів нагадувала ієрогліф «колодязь». Члени так званої шини із 8 сімей, крім обробки своїх полів, які розміщувались по краям, повинні були обробляти поле правителя, яке знаходилось в центрі. Філософ 4 століття до н. е. Мен-Цзи вважав, що китайська система землекористування $є$ ідеальною i відносив її розквіт до початку першого тисячоліття до н.е. Принцип зрівняльного землекористування, при якому обробка свого поля поєднувалась 3 колективною обробкою «великого поля» на користь держави, зберігався в Китаї протягом багатьох тисячоліть. Держава також суворо регламентувала заняття селян, визначаючи, що їм виробляти, і в якій кількості.

Визначальна роль держави потребує великого бюрократичного апарату чиновників. Чиновники одержували платню у вигляді зерна та інших продуктів, а також вони отримували від держави земельні наділи, розмір яких залежав від рангу чиновника. Для того, щоб стати чиновником, потрібно було пройти через систему дуже складних іспитів, склавши які можна було зайняти певну посаду. Щоб скласти іспит, потрібно було дуже довго i наполегливо платно вчитись, продемонструвати глибокі пізнання в філософії і поезії, а також треба було знати величезну кількість державних законів та інших регламентацій, які були необхідні для несення служби. Конкуренція була дуже жорсткою - 100 чоловік на одне місце. Людина, яка продемонструвала глибокі знання та склала іспит на посаду чиновника, була оточена величезною повагою, славою і почестями. Тому повага до знань, до освіченості, до системи освіти, розуміння іiі ролі як певного соціального ліфту, є ще одним важливим історичним витоком китайської моделі економіки.

Важливою рисою азійського способу виробництва була східна деспотія. Ї̈ї класичним прикладом $\epsilon$ жорстоке правління імператора Цинь Ши-хуанди (III ст. до н.е.). Але визначальна риса східної деспотії - це не скільки жорстокість окремих правителів, а державна регламентація усіх сторін життя. Держава регламентувала, що повинен вирощувати кожен селянин, як він це повинен робити, що повинен виробляти ремісник, як треба ремонтувати канали i зрошувальні системи, коли і 3 ким торгувати і т. і. I хоча історично пізніше в Китаї з'являється і приватна власність на землю, і орендні відносини, провідні позиції залишаються за державою. Наприклад, вже набагато пізніше, в 1912 році, селяни, які вели господарство на державній землі, складали 49\%, напіворендарі - 23\%, орендарі - 28\% [4, p. 137].
Оскільки напіворендарі наполовину також вели господарство на державній землі, то це означає, що майже $72 \%$ селян вели господарство на державній землі. Слід зазначити, що ідеалом для китайського селянина завжди залишалася державна власність на землю, яка була лозунгом багатьох селянських повстань.

Драматичною сторінкою в історії Китаю стали так звані «опіумні війни» XIX століття. На початку XVIII ст. Китай був досить багатою країною, економіка якого по загальному рівню розвитку займала передові позиції (була першою економікою світу за деякими даними). На відміну від Японії, в Китаї ніколи не проводилась політика ізоляції від зовнішнього світу. Все почалось 3 того, що правителі Китаю звернулися за допомогою до іноземців для приборкання тайпінського повстання (18501864 рр.) - кривавого селянського повстання проти манжурської імперії Цін, в ході якого від війни, голоду і епідемій загинуло 118 млн. чол. В результаті Китай отримав не лише допомогу, але й величезний борг, для виплати якого весь збір податків був переданий в руки іноземців. Територія Китаю була розподілена на сфери впливу між імперіалістичними країнами. Іноземці були непідсудні китайському суду, i їх руках був флот, війська, поліція, а китайський уряд не мав реальної влади. В руках іноземців була і зовнішня торгівля, при цьому 46\% китайського імпорту в ХІХ ст. складав опіум, який нелегально поставляла Великобританія, яка до цього мала негативне сальдо в торгівлі з Китаєм. Китаю було заборонено вводити мито на іноземні товари більше ніж 5\%, тому імпорт дешевої англійської фабричної продукції, подавляв розвиток китайської промисловості. В руках іноземців крім зовнішньої торгівлі і збору податків, був залізничний транспорт, $50 \%$ вугільної та 40\% текстильної промисловості. При цьому розміщення промисловості було вкрай нераціональним, оскільки 75\% промисловості було розміщено в північно-східних районах. Тільки в одному Шанхаї функціонувало 50\% всієї легкої промисловості країни [5]. В більшості районів Китаю промисловості не було зовсім.

Китайська революція проти іноземного капіталу продовжувалася 25 років, (з 1924 р. по 1949 р.), і складалась 3 3-х громадянських війн і національновизвольної війни проти Японії. Закінчилась вона проголошенням в 1949 році КНР. За досить короткий час - з 1949 по 1952 роки був відновлений довоєнний рівень економіки. В 1950-1952 рр. була проведена аграрна реформа. Земля була конфіскована у великих землевласників та розподілена між селянами. Кожний селянин отримав наділ землі розміром від 1 до 3 му (1 му дорівнює 1/16 га). Були націоналізовані підприємства іноземців та компрадорської буржуазії. 31955 року почалось перетворення капіталістичних 
підприємств в державно-капіталістичні, 3 яких капіталісти повинні були отримувати $25 \%$ прибутку. Така система отримала назву «чотирьом коням по мірі вівса»: 25\% прибутку капіталістам, 25\% державі, 25\% - на розвиток підприємства, 25\% - на покращення становища робітників. Пізніше система була змінена - власник підприємства отримував лише 7\% прибутку, а потім і взагалі отримав статус державного службовця.

Таким чином, основний принцип азійського способу виробництва - провідна роль держави та державної власності, став головним і на цьому етапі соціально-економічного розвитку Китаю.

В 1958 році відносно помірний курс економічного розвитку був замінений курсом «трьох прапорів»: генеральної лінії, великого стрибка та народних комун. Завдання трьох п'ятирічок було вирішено виконати за декілька років. В Китаї в 1960ті роки $86 \%$ населення було сільським, i, відповідно, лише $14 \%$ населення Китаю жило в містах, а робітники і службовці складали лише 7\% населення [6, с. 352]. Одна із особливостей азійського способу виробництва полягала в тому, що китайський селянин одночасно був i сільгоспвиробником i ремісником. В проміжках часу між сезонною сільськогосподарською працею селяни завжди виготовляли примітивну промислову продукцію. Це i привело до намагання підвищити рівень промислового виробництва в Китаї за рахунок кустарного промислу, зокрема через кустарну виплавку чавуну, що закінчилось плачевно.

Після провалу політики «великого стрибка» почався період політики «вирівнювання», і для того, щоб зупинити падіння економіки, головні сили були переключені на сільське господарство і легку промисловість. Був запропонований лозунг самозабезпечення: люди повинні були працювати фактично безкоштовно на державу, а в вільний від роботи час займатись самозабезпеченням на основі ведення натурального господарства. Таким чином формувались два рівня економічного розвитку:

- архаїчне натуральне господарство, за рахунок якого повинно було жити населення, його самозабезпечення на основі вкрай низького життєвого рівня;

- державний сектор економіки, який повинен орієнтуватись на експорт і розвиватись не скільки за рахунок великих капіталовкладень, скільки за рахунок майже безоплатної праці мільйонів людей.

Критичні наслідки для розвитку соціальноекономічного життя в Китаї мала і «культурна революція» 1966-1976 pp. Широкомасштабні репресії проти інтелігенції, розгром громадських організацій, знищення пам'яток культури, зниження рівня науки і освіти, завдали колосальної шкоди.

Подальше падіння виробництва та рівня життя населення потребувало кардинальних реформ. Рішення про такі реформи було прийнято в 1978 році. Реформи в КНР цього періоду мали ряд особливостей.

По-перше, вони були направлені лише на економічні зміни. Політично нічого не змінювалось, оскільки правлячою як i раніше залишалась комуністична партія Китаю, яка продовжила курс на соціалізм 3 «китайською специфікою».

По-друге, в країні в ході ринкових реформ не проводилась приватизація. Жодне державне підприємство не було приватизоване. Всі китайські приватні підприємства були створені 3 нуля, на основі приватних інвестицій. Слід зазначити, що сам термін «приватизація» і на сьогодні має в Китаї негативне значення.

По-третє, в країні залишалась система директивного планування, а ринок повинен був доповнювати державні плани. Держава планувала виробництво найважливіших видів промислової продукції і установлювала ціни на них. Оптова закупівля сільгосппродукції також здійснювалась лише державою по встановленим нею цінам.

Реформа почалась з сільського господарства, в якому була зайнята більшість населення. Селянин отримав в оренду наділ землі, в середньому 0,5 га на господарство, на 50 років. 3 державою він заключав контракт на поставку певної кількості певного виду продукції. Продукцією, що залишається, селянин розпоряджався за власним бажанням.

В промисловому розвитку Китаю в цей період суттєву роль зіграв іноземний капітал. В країні були створені «спеціальні економічні зони», де для іноземного капіталу існували дуже сприятливі умови. Пізніше ці зони були розширені до 14 прибережних міст та трьох районів. Заробітна плата на цій частині території була набагато більшою, ніж в інших районах Китаю. Але в цілому середня заробітна плата в Китаї в 1990-х роках була в 20 разів нижче, ніж в США, і така дешева робоча сила дуже приваблювала іноземних підприємців. Досить привабливими були і умови оподаткування. Урядом також були прийняті закони про контракти, патенти та по іншим питанням, що представляли інтерес для іноземних підприємств. Китай отримав кредити від Світового банку, від Японії та ряду комерційних банків, а також фінансування по програмам $\mathrm{OOH}$.

Таким чином, Китай використовував декілька каналів залучення інвестицій, серед яких займи від іноземних держав, кредити від міжнародних фінансових організацій, іноземних комерційних банків, експортні позики, облігації зовнішнього займу, прямі іноземні інвестиції, включаючи підприємства із змішаним капіталом, спільні підприємства і підприємства із 100\% - ним іноземним капіталом; інші зарубіжні інвестиції (міжнародний 
лізинг, компенсаційна торгівля, створення потужностей 3 переробки сировини та складальних підприємств, а також емісію акцій на зовнішньому ринку).

В 1990 р. в КНР було вкладено 3,5 млрд. дол. прямих іноземних інвестицій, у 1995 р. - 37,5 млрд., 2000 р. - 40,7 млрд., 2001 р. - 46,9 млрд. дол. [7]. У цілому в 1979-2001 рр. в Китай було вкладено 394 млрд. дол. іноземних інвестицій [7]. По сумі заполучених зарубіжних інвестицій КНР виходить на друге місце в світі після США. На початку 2002 р. в Китаї були накопичені інвестиції зі 170 країн світу, а кількість підприємств з іноземним капіталом досягло 390 тис. Із 500 провідних ТНК світу 400 інвестували капітал в економіку КНР [8]. Однак підкреслимо такий важливий факт: 70-80\% іноземних інвестицій приходилось на долю так званих «хуацяо»- етнічних китайців, які в свій час емігрували 3 країни i збагатились на чужині. Основними територіями надходження інвестицій стали Гонконг і Тайвань. На початку 2000-х років підприємства 3 іноземним капіталом давали 25\% промислового виробництва країни.

З 1990 року в Китаї почали працювати фондові біржі в містах Шанхай та Шеньчжен, а в 2003 році уряд дав дозвіл першим іноземним фірмам проводити торги на ринку. В 2001 р. були емітовані 84 види акцій виду А і 126 видів додаткових акцій, в тому числі 9 видів акцій В і Н, а також акції серії «червоні фішки». Біржевий ринок КНР розвивається надзвичайно високими темпами. В ньому приймають участь 1,16 тис. компаній и 66,5 млн. інвесторів [9]. Шанхайська і Шеньчженьська фондові біржі стали найбільшими біржами світу, де щоденно відбуваються фондові операції на мільярди доларів. На сьогодні за капіталізацією фондового ринку Китай посідає друге місце в світі, а китайський юань з 2016 року входить до кошику резервних валют МВФ. 3 2018 року на Шанхайській міжнародній енергетичній біржі розпочалась торгівля нафтовими ф'ючерсами, номінованими в юанях.

Знакові зміни відбулись в фінансово-кредитній системі країни. В 1994 році Торгово-промисловий банк Китаю, Банк Китаю, а також Будівельний та Сільськогосподарський банки були перетворені в комерційні банки. Були також створені нові банки Державний банк розвитку, Імпортно-експортний банк, Сільськогосподарський банк розвитку. В 1996 році були створені перші комерційні приватні банки і сфера банківських послуг значно розширилась. В 1998 році Народний банк КНР створив систему контролю за банківськими операціями, фінансовими потоками, страхуванням, операціями з акціями. Було створено 9 нових філіалів цього банку.

В 1980-1990 роки розширялась діяльність іноземних фінансових структур на китайському ринку. В 23 містах КНР і в провінції Хайнань діють 190 фінансових структур з іноземним капіталом. В 1999 році банки 3 іноземним капіталом отримали право відкривати філіали в містах центрального підпорядкування [10].

Китай є членом МБРР и МВФ. В 1985 р. КНР стала членом Африканського банку розвитку, а в 1986 р. - Азійського банку розвитку.

В 1994 році в Китаї була проведена реформа валютної системи. Були введені єдині курси основних валют до юаню, створена система валютних розрахунків, продаж і переказів, на основі чого був організований міжбанківський валютний ринок. В 1996 році операції 3 купівлі-продажу валюти на зарубіжних ринках були включені в банківську систему конвертації. В кінці 1996 року в КНР була введена в дію ст. 8 договору з МВФ і введений обмін юаня на зарубіжні валюти. Обмінний курс юаню встановлюється Народним банком i публікується Головним державним управлінням валютного контролю.

Таким чином, зміни в економічній стратегії і в економічному розвитку Китаю з 1978 р. вражають. В останні 25 років Китай є світовим лідером 3 точки зору темпів економічного зростання, які досягаються на основі сполучення принципів планового регулювання з ринковими методами, в тому числі на основі централізованого визначення темпів i пропорцій розвитку економіки. В 2022 році виповниться 70 років розвитку економіки КНР на базі народно - господарських планів. Хоча слід зазначити, що в останні роки темпи зростання економіки КНР зменшуються. В 1990-ті роки вони складали 10-12 \% за рік, в 2017 році - 6,8\%, в 2018 році зменшились до $6,6 \%$, а в 2019 році темпи економічного розвитку Китаю складали 6,1\% [11].

В ході реформ, одночасно 3 глибокими структурними змінами в економіці, найбільш високими темпами в Китаї розвивалась промисловість. В 1990-2001 рр. темпи зростання виробництва електроенергії складали 9\% в рік. Китай став виробляти газові турбіни, енергоблоки для атомних станцій, комплектне обладнання для виробництва хімічних добрив, нафтохімічної продукції, целюлознопаперової, текстильної та інших галузей. Прискореними темпами розвивалась автомобільна промисловість. В 1995-2000 pр. виробництво автомобілів виросло з 1,45 до 2,07 млн., в тому числі легкових - 3 323 тис. до 607 тис. (темп зростання 19\%) [8].

Сучасна структура промисловості Китаю представлена 360 галузями [7]. Поряд 3 традиційними галузями виробництва: вугільна, текстильна, хімічна, газова, електроенергетика, створені такі нові галузі як електроніка, нафтохімія, авіабудування, металургія рідких та розсіяних металів. Китай займає перше місце в світі по виробництву телевізорів, 
цементу, мінеральних добрив, металорізальних верстатів, тканин, м’яса, зерна.

Головні центри промислового виробництва в Китаї це Шанхай, Шеньян, Далянь, Пекін, Шеньжень, Гуанчжоу. Серед галузей китайської промисловості найбільшими темпами зростає виробництво комп'ютерних комплектуючих, кольорових телевізорів, мобільних телефонів, автомашин, кондиціонерів, хімічних волокон, металопродукції та інших товарів з високою доданою вартістю. А на початку XXI ст. Китай став ще й космічною та ядерною державою.

В розвитку китайської моделі економіки особливо важливу роль відіграє зовнішня торгівля. У 2001 р. Китай став членом СОТ, що надало йому нових можливостей. Тарифи i обмеження на торгівлю 3 іншими країнами зменшувались, це відкрило для Китаю нові горизонти, дало можливість продавати китайські товари по всьому світу і стати «майстернею світу».

В структурі сучасного експорту КНР 57\% продукція машинобудування, а доля технологічної та високотехнологічної продукції складає 28\% [5]. Китай є основним експортером сталі у світі.

В структурі зовнішньої торгівлі велику роль відіграє i експорт споживчих товарів, що дало підстави називати Китай світовою фабрикою 3 їх виробництва. 3 метою відійти від моделі світової фабрики, яка виробляє дешево, але низької якості, в 2015 році в Китаї була ухвалена програма розвитку високотехнологічної промисловості «Зроблено в Китаї - 2025», мета якої сформувати новий імідж Китаю як виробника продукції з високою якістю [5]. Програма направлена на розвиток таких галузей як IT-індустрія, аеро-космічна, робототехніка, фармацевтична, випуск напівпровідників і автомобілів. 3 цією ж метою в районі Хайдянь, північніше Пекіну, створена китайська «Силіконова долина». В КНР уже зараз більш ніж 384 мільйонів користувачів Інтернет, країна $є$ світовим лідером по кількості користувачів мобільного зв'язку.

Але в останні роки Китай отримує на зовнішньому ринку доходи не лише від торгівлі. Економічні успіхи КНР перетворили сучасний Китай в одного 3 найбільших кредиторів світу. Так, за період з 2000 р. по 2017 рік заборгованість інших держав перед КНР збільшилася майже в 10 разів: 3 500 млрд. дол. до майже 5 трлн. дол. ( з 1\% до 5\% світового ВВП). На думку експертів, такі величезні суми надання міжнародних кредитів перетворили Китай в одного з найбільших офіційних кредиторів, який значно випереджає МВФ та Світовий банк [12].

Доходи від експорту - надзвичайно важливе джерело доходів, що направляються на економічне зростання, на структурну перебудову економіки, іiі розвиток і перетворення. По об'єму експорту КНР займає 1-е місце в світі. Експорт дає $80 \%$ валютних доходів держави. Саме цим можна пояснити досить жорстке державне регулювання зовнішньоекономічних зв'язків Китаю. Держава, не коливаючись вводить обмежувальні заходи, якщо це потрібно для захисту національних інтересів і зовнішньої торгівлі. 3 урахуванням того, що основним ринком збуту китайських товарів $є$ ринок США, періодично можна спостерігати китайсько-американські торгові війни, які негативно впливають на розвиток китайської економіки (хоча економіка США також від них не виграє).

В структурі імпорту КНР переважну долю займає продукція машинобудування та транспортні засоби. В Китаї підтримується і система імпорту технологій, що дозволяє розвивати такі перспективні напрями економіки як розробка програмного забезпечення, телекомунікаційна індустрія, виробництво нових матеріалів, біотехнології, медична i фармакологічна промисловість.

В моделі китайської економіки особливе місце займають соціальні реформи і підвищення рівня життя населення країни. В 1949 році, коли була проголошена КНР, в країні проживало 425 млн. осіб. В 2020 році населення Китаю становило майже 1,4 млрд. чол. Тому для країни 3 такою величезною кількістю населення, проблема підвищення рівня життя та соціального захисту людей була i залишається надзвичайно складною. Уже на першому етапі реформування економіки, в 19782001 рр. доходи на душу населення зростали в середньому на 6,4\% в рік і збільшились в містах з 343 до 6860 юаней, або в 20 разів, а доходи сільських жителів із 134 до 2366 юаней (в 17,6 рази). Доля видатків на харчування в сумі видатків міського населення складала в 1978 р. 57,5\% , а в 2001 р. 37,9\%; сільських жителів відповідно 67,7 и 47,7\%. В структурі споживання населення в 1979-2002 pр. збільшилась доля видатків на житло, транспорт, медичні послуги та задоволення культурних потреб $[13$, с. 26].

Фундаментом для кардинальних соціальних реформ у Китаї стали нова Конституція (1982 р.) та Закон про працю (1994 р.) [13, с. 29]. У 2007 р. було затверджено, а в 2012 р. - значно розширено програму соціального розвитку КНР, в якій визнавалося право громадян на освіту, медичне обслуговування, зайнятість і пенсійне забезпечення у старості. В результаті, якщо у 2003 р. медичне страхування було тільки у $3 \%$ сільських жителів, які мають на нього право, то на сьогодні - майже $98 \%$ $[14$, c. 75$]$.

Однак слід констатувати, що у рівнях життя населення у містах i селах i досі збереглася колосальна різниця. Рівень прихованого безробіття в сільській місцевості майже в 2 рази перевищує 
офіційні показники (4,6 \%). Між цими двома групами населення Китаю знаходиться великий прошарок мігрантів і незареєстрованих робітників, які мають мізерні соціальні права порівняно із звичайними громадянами країни. 3 метою вирішення цієї проблеми у 2006 році було створено Об'єднаний комітет з міграції сільського населення. Правлячою партією Китаю була поставлена задача побудови суспільства середньої заможності, що свідчить про те, що держава бажає, щоб усі жителі Китаю відчули на собі позитивний результат розвитку країни і жили за загальної заможності.

Для підтримки високих темпів соціальноекономічного розвитку та подальшого підвищення якості життя, Китай в останні десятиріччя активно розвиває власну систему освіти, а також активно підтримує навчання китайських студентів в зарубіжних університетах, і в першу чергу в США та Японії. 32007 р. по всій країні запроваджено систему обов'язкової початкової освіти дітей. На сьогодні китайська система освіти розвивається дуже динамічно i демонструє позитивну динаміку в світових рейтингах.

\section{Висновки}

Таким чином, економічна модель Китаю, яка в самій країні отримала назву моделі ринкового соціалізму, $\epsilon$ не лише конкурентоздатною, але й досить стійкою по відношенню до кризових явищ сучасності. Історичними витоками цієї моделі $\epsilon$ азійський спосіб виробництва та особлива модель держави, яку прийнято називати «конфуціанською».

Характерними рисами китайської моделі економіки є:

- сильна держава 3 масштабним державним сектором економіки;

- активне втручання держави в макроекономічне регулювання, планування та прогнозування соціально-економічного розвитку;

- багатоукладність економіки, ефективне поєднання різних форм власності, сполучення традиційних і сучасних укладів;

- конфуціанська модель справедливої держави, що повинна створювати рівні можливості для саморозвитку кожного;

- провідна керуюча роль правлячої партії;

- економічний розвиток як найвища мета державної політики;

- жорстке регулювання зовнішньоекономічної діяльності з боку держави;

- глибока залежність добробуту i безпеки індивідів від сімейних цінностей;

- особлива роль національного менталітету, традицій і звичаїв;

- високий рівень дисциплінарної культури та стабільна організація суспільства;
- панування настанов прагматизму та раціоналізму.

Найважливішою особливістю китайської моделі економіки є і те, що в умовах фінансової глобалізації, коли обсяг світових фінансових ринків в 50 разів перевищує обсяг світового ВВП, і в 70 разів перевищує обсяг світового товарообігу (по сумах щоденних операцій), країна активно розвиває реальний сектор економіки. В китайській моделі як основний інструмент глобальної конкуренції та показник конкурентоспроможності розглядаються нові технології та інноваційні галузі, які підтримуються урядовими програмами технологічних інновацій і перебудови управління.

Сучасні особливості китайської моделі економічного розвитку чітко проявили себе і в ініціативі КНР, яка отримала назву «Один пояс, один шлях». Мова йде про розвиток міжнародної прагматичної співпраці з країнами Поясу і Шляху, створенні міжнародних метрологічних систем та спільної системи інновацій. Ця ініціатива $\epsilon$ прикладом мирного поширення присутності КНР в системі міжнародних відносин, проявом іiі культури, традицій і цінностей.

Економічні успіхи Китаю показують, що його економічна модель організована суттєво інакше, ніж «зразкові» західні моделі. Китайська альтернатива ліберальній соціально-економічній моделі стосується, перш за все, ролі держави в економіці. Не дивлячись на те, що в кінці 1990-х років доля держави в ВВП КНР зменшилась з 70\% до 40\%, а доля зайнятих в державному секторі економіки скоротилась з 95\% до 18\%, в важкій промисловості держава зберігає за собою провідні позиції. В 1996 р. на державних підприємствах було отримано 28,5\% промислової продукції і було зайнято $66 \%$ робітників і службовців в промисловості [7].

Сучасна економічна наука звертає увагу на так званий новий «азійський» цикл накопичення у глобальній економіці. Стає очевидним, що в кінці XX i на початку XXI ст. західна економіка почала поступатися своїми можливостями та перевагами країнам і економікам Великої Азії. В сучасному глобалізованому світі починається етап найбільш гострої конкуренції за майбутнє технологічне лідерство. Одним із найважливіших центрів такої конкуренції $\epsilon$ Китай, планова модель економіки якого демонструє світу високий ступінь організованості іiі державної системи і їі здатність адаптуватись до викликів сучасності.

\section{Література}

1. Аналітичні дані Світового банку: Офіиійний сайт [Електронний ресурс]. - Режим доступу: URL: http://databank.worldbank.org/data/databases.aspx - Назва 3 екрану. 
2. National Bureau of Statistics of China, UNCTADstat, World Bank. Офіиійний сайт [Електронний ресурс].

3. Дроботюк О.В. Еволюиія моделі економічного розвитку КНР / О.В. Дроботюк // Украӥна - Китай. - 2019. - № 3(17).

- C. 32-48.

4. Wong L. Marginalization and Social Welfare in China. London: Routledge, 1999. - 432 P.

5. Економіка Китайської Народної Республіки / Агентство Сіньхуа. - URL Oфіційний сайт [Електронний ресурс]. Режим docmyny:

http://russian.news.cn/china/economic.htm. - Назва з екрану. 6. B. Noton. The Chinese Economy Transitions and GrowthNew York: 2016. - 450 P.

7. Економіка Китаю. Структура экономіки Китаю: [Електронний ресурс]. - Режим доступу: http: //www.ereport.ru/articles/weconomy/china2. htm.

8. Нестеров А.К. Современная экономика Китая: [Електронний ресурс]. - Режим docmyny: http://odiplom.ru/lab/sovremennaya-ekonomikakitaya.html Назва з екрану.

9. Gao Q., Yang S., Li S. The Chinese Welfare State in Transition: 1988-2007 // Journal of Social Policy. - 2013. Vol. 42. - P. 743-762.

10. Giovanni J., Levchenko A., Zhang J. The Global Welfare Impact of China: Trade Integration and Technological Change // IMF Working Paper. - 2012. - № 79.

11. Saich T. Governance and Politics in China. New York, Palgrave Macmillan, 2011. Working Paper

12. Global Capital Markets: Entering a New Era / McKinsey Global Institute: [Electronic resource]. - Access mode: http://www.mckinsey.com/mgi

13. Zheng G.C. China's Social Security in Thirty Years. Beijing: People's Press, 2008. - P. 21-38.

14. Длугопольський О.В. Держава (загального) добробуту в Китаї: етапи становлення і проблеми перебудови / О.В. Длугопольський // Економіка Украӥни. - 2014. - № 7. C. $69-81$.

\section{References}

1. Analytical data of the World Bank: official website. Retrieved from

http://databank.worldbank.org/data/databases.aspx

2. National Bureau of Statistics of China, UNCTADstat, World

Bank. The official site [electronic resource].

3. Drobotyuk O. V. (2019) Evolution of the model of economic development of the China. Ukraine-China, 7, 32-48.
4. Wong L. (1999) Marginalization and Social Welfare in China. Routledge

5. Economics Of The People's Republic Of China / Xinhua Agency. Retrieved from http://russian.news.cn/china/economic.htm.

6. Noton B. (2016) The Chinese Economy Transitions and Growth. New York.

7. The Chinese Economy. Structure of the economy of China Retrieved from http: //www.ereport.ru/articles/weconomy/china2.htm.

8. Nesterov A.K. (2018) Modern economy of China. Retrieved from http://odiplom.ru/lab/sovremennaya-ekonomikakitaya.html

9. Gao Q., Yang S. \& Li S. (2013) The Chinese Welfare State in Transition: 1988-2007. Journal of Social Policy, 42, 743762.

10. Giovanni J., Levchenko A. \& Zhang J. (2012) The Global Welfare Impact of China: Trade Integration and Technological Change. IMF Working Paper, № 79.

11. Saich T. (2011) Governance and Politics in China. Palgrave Macmillan.

12. McKinsey Global Institute (2020) Global Capital Markets: Entering a New Era. Retrieved from http://www.mckinsey.com/mgi

13. Zheng G.C. (2008) China's Social Security in Thirty Years. People's Press.

14. Dlugopol's'kyi A. V. (2014) The state of (total) welfare in China: stages of formation and problems of construction. Economy of Ukraine, 7, 69-81.

Рецензент: д-р екон. наук, проф., проф. каф. земельного адміністрування та геоінформаційних систем Мамонов К.А., Харківський національний університет міського господарства імені О.М. Бекетова, Україна.

Автор: РЕШЕТИЛО Валентина Петрівна доктор економічних наук, професор кафедри економічної теорії та міжнародної економіки

Харківський національний університет міського господарства імені О.М. Бекетова

E-mail-kafedraekteor@gmail.com

ID ORCID: https://orcid.org/0000-0001-7511-7279

\title{
HISTORICAL ORIGINS OF THE FORMATION OF THE CHINESE ECONOMIC MODEL
}

\author{
V. Reshetilo
}

O.M. Beketov National University of Urban Economy in Kharkiv, Ukraine

The article analyzes the history of formation, main features, characteristics and stages of development of the Chinese economy, which has been demonstrating economic growth over the past decades. The country's economic success is updated by research on the historical origins, place and role of the Chinese economic model in global economic development. In the historical context, the origins of the Chinese model of economy are seen in the main features of the Asian mode of production, the constant presence of the state in the regulation of public life and in economic development.

It is characterized that the formation of the Chinese model of the economy began with the economic reforms of 1978, the features of which were focused only on economic changes with an unchanged political system; the absence of any privatization and the creation of private enterprises from scratch during market reforms; the leading role state 
regulation and national economic plans in the development of the economy. The characteristic features of the modern Chinese model of the economy include: a strong state with a large-scale public sector of the economy; active state intervention in macroeconomic regulation, planning and forecasting of socio-economic development; a multi-layered economy, an effective combination of various forms of ownership, a combination of traditional and modern ways of life; the implementation of the Confucian model of a just state, which should create equal opportunities for selfdevelopment of everyone; the special role of national mentality, traditions and Customs; a high level of disciplinary culture and stable organization of society; the dominance of pragmatism and rationalism.

It is investigated that the most important feature of the Chinese economic model is the development of the real sector of the economy, and the main tools of global competition are considered here new technologies and innovative industries that are supported by government programs.

Keywords: Asian method of production, Confucian model of the state, Chinese model of the economy, reforms, economic development, real economy. 